\title{
Current Trends of Muslim Academia in Comparative Religions
}

\author{
Andleeb Gul \\ Government College University, Lahore
}

\begin{abstract}
Throughout the history of the study of religion or religions, many scholars had emerged and contributed to this vocation. Many international scholars; be them from the east and west, Muslims or non-Muslims; recognize Muslim scholarship in Religionswissenschaft (Religious Studies). In sum, comparative study of religions is regarded as one of the great contributions of Muslim's civilization to mankind's intellectual progress. Nevertheless, when referring to the popular works of Muslim scholars in this discipline, most people will refer to only some treatises with negligence to the great bulk of Muslim Heritage in Religionswissenschaft. Many approaches and styles are found in purposive treatises by Muslims in the field of Religionswissenschaft. Some of them are descriptive in nature; some are disputative, polemical and apologetic, which involve defending, refuting, and extensive criticism; while some others are analytical, involving serious studies of certain aspects of other religions. The treatises produced by Muslim scholars on other religions are not necessarily limited only to one particular style, for some of them employ different approaches. But despite of such a rich heritage Muslim thought in context of religious studies is currently stagnant. Main stream text and approaches in Muslim academia revolves largely around whether savage refutation or apologetic. Contemporary researches stands far away from the modern approaches and theories known in field of Religious Studies like those of Polymethodic Studies, Methodological Neutralism, Ethnographic approaches. The paper intends to explain the problem and suggest Muslim academia what steps to take, by presenting the analysis of its current trends and Muslim heritage in the field, to move forward in thought process in the field of Religious Studies coping up with the contemporary theories in academic as well as social context.
\end{abstract}

Keywords: outsiders, insiders, religious studies, comparative religions, Muslim Heritage

\section{Defining Comparative Religions}

In current context Comparative Religions stands as the branch of study Religions which revolves around systematic comparison of faiths. But this simple notion does not stand as easy as it appears it stands with many layers in itself. The notion is differently interpreted by Insiders and outsiders thus both establishing different grounds of productivity. 


\subsection{Insiders}

By insiders it simply means the people with faith who believe religion to be a divine phenomenon for them religion is an absolute sole truth. But as there stands many religions truth has to be one. To establish these insiders, pursue comparative studies in between religions or even within religions in order to establish sectarian facts.

\subsection{Outsiders}

Scholars who treat religion as a phenomenon of human concise, they involve in the studies of religions and further comparative studies to establish generalizations about certain group, faith and their practices.

\subsection{Debate of Insider and Outsider}

Debate over the study of religions in between insiders and outsider is the most debated phenomenon of the time. Insiders points out that the outsiders are unable to get a full grasp of religious experiences while on the other hand outsiders' claim that insiders lack the neutralism in the comparative studies. With the same objective of studying religions both of the group have come up to involve in a destructive debate rather than constructive. The question is that why can't the insiders borrow neutralism and outsider the understanding of experiences? ${ }^{1}$

\section{Muslim Heritage in the Field}

The interest of students in Qur'ānic perspective of other religions have always been in his full passion from the very beginning of Muslim Intellectual history. It has been the subject of various writings by Muslims and non-Muslims, scholars and researchers of religions, philologists and history specialists - some favoring interreligious relations, others communicating reservations about them. Since the Qur'ān is the establishing scripture of Islam and on the grounds that Qur'ānic verses are considered Words of God, comprehending what the Qur'ān says in regards to different religions and understanding what is meant by these passages is indispensable in the case that one needs to get a handle on the relations amongst Muslims and non- Muslims. All through Islamic history Muslim exegetes have focused on this issue, now and then demonstrating much resourcefulness in talking about it.

Throughout the history of the study of religion or religions, many scholars had emerged and contributed to this vocation. Many international scholars; be them

\footnotetext{
${ }^{1}$ Russell McCutcheon, The Insider / Outsider Problem in the Study of Religion (London:
} Cassell, 1998). 


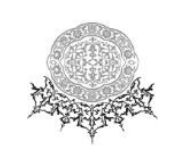

from the east and west, Muslims or non-Muslims; recognize Muslim scholarship in Religionswissenschaft. In sum, comparative study of religions is regarded as one of the great contributions of Muslim's civilization to mankind's intellectual progress. Nevertheless, when referring to the popular works of Muslim scholars in this discipline, most people will refer to only some treatises with negligence to the great bulk of Muslim Heritage in Religionswissenschaft. ${ }^{2}$ Many approaches and styles are found in purposive treatises by Muslims in the field of Religionswissenschaft. Some of them are descriptive in nature; some are disputative, polemical and apologetic, which involve defending, refuting, and extensive criticism; while some others are analytical, involving serious studies of certain aspects of other religions. The treatises produced by Muslim scholars on other religions are not necessarily limited only to one particular style, for some of them employ different approaches.

Muhammad Khalifah who has been the vice-president of the International Islamic University Islamabad maintains, "The voluminous contributions of the medieval period to the study of religion(s) established this study as an independent science for the first time." He has written a doctoral dissertation for the Temple University on the theme of "Medieval Jewish-Muslim contribution to the Academic Study of Religion." As the title of his dissertation is suggestive, he refers to this tradition as 'the academic study of religions,' and considers it a part of the history of Religionswissenschaft and freely uses the contemporary terminology like phenomenology of religion, eidetic vision, epôché and so on to describe its tenets. ${ }^{3}$

At least three authors use the expression 'early Muslim scholarship in Religionswissenschaft.' The first one is a Malaysian academician Kamar Oniah Kamaruzaman who uses this expression in connection with the contributions of Abu Rayhān al-Bīrūnī (362/973-443/1048). The other two author use the term Religionswissenschaft with reference to the work of 'Abd al-Karīm al-Shahrastānī (479/1086-553/1153) in the title of a book section. Apparently, the term is taken here in generic sense meaning comparative study of religions rather than the particular approach to religion which surfaced in Western Europe during the later half of the nineteenth century with this label. Two other articles by Kamaruzaman support this inference, one of which refers to the work of al-Bīrūni using the term Religionswissenschaft while the other substitutes it with 'Comparative Religion' in the same context.

Another set of studies endeavors to elucidate the characteristics and methodologies of the classical Muslim studies on other religions. Muhammad 63.

${ }^{2}$ William Thomson, "Islam and the Early Semitic World," The Muslim World 39 (1949): 36-

${ }^{3}$ Jamshed K. Choksy, "Conflict, Coexistence, and Cooperation: Muslims and Zoroastrians in Eastern Iran during the Medieval Period," in Muslim World 80, no. 3-4 (1990): 213-233.

JOURNAL OF ISLAMIC THOUGHT AND CIVILIZATION 


\section{사}

'Abdullāh Drāz (1312/1894-1378/1958), one of the most widely known Arab authors on the subject - maintains that the Muslim scholars "derived there from trust worthy and original sources and so they developed it into an independent science, they gave it a sound scientific method. They have the credit of establishing it as an independent science, ten centuries before the modern Europe did the same." interesting but somewhat simplistic comparison of the methodologies of Abū alAsan al-'Āmirī (300/912-381/992) and al-Bīrūnī with those of Mircea Eliade (19071987) and Joachim Wach (1898-1955) is found in 'Isa Muhammad Maishanu's doctoral thesis which he wrote for the International Islamic University Islamabad, Pakistan. A much more profound exposition of the sources, methodologies and overall worth of the classical Muslim scholarship is found in the article titled Min Manāhij 'Ulamā' al-Muslimīn fì Dirāsat al-Adyān (Some Methods of the Muslim Scholars in Study of Religions) by Dīnmu Ammad presently based at the University of Qatar.

However, when referring to the popular works of Muslim scholars in this discipline, most people will refer to only few treatises with negligence to the great bulk of Muslim Heritage in Religionswissenschaft. This is due to the nature of this study, which recognizes and calls for the understanding of the pluralistic nature of human faith. The religion of God is one, but the religions of humankind are multiple in number. This recognition and calling for the understanding of the various kinds of human religions are enshrined in the Holy Qur'ān. Muslims learn this fact from the Qur'ān and in the passage of time; many prominent ulamas (Islamic religious scholars) emerged as scholars of Religionswissenschaft.

The early Muslim scholars in this discipline were Al-Nawbakhti (d. 202H) through his al-Ara' wa Al-Diyanat, al-Masudi (d. $346 \mathrm{H})$ through his al-Diyanat, alMusabbihi (d. 420H) Dark Al-Bughiyyah fi Wasf Al-Adyan wa al-Ibadat, alBaghdādi's (d. 429H) al-Milal wa al-Nihal, Ibn Hazm's (d. 456H) al-Fisal Fi alMilal wa al Ahwa' wa al-Nihal, Al-Shahrastān̄’'s 's (d. 548H) al-Milal wa al-Nihal and al-Biruni's (d. 440H) Tahqeeq ma li al-Hind Min Maqulah Maqbulah Fi alAqlaw Mardhulah. Unfortunately, many of these early works were only noted in the pages of historical books of manaqib, tabaqat and tarikh; whereby only a few of them managed to survive to the present day for academic reference and analysis.

\subsection{Ibn Hazm (994 - 1064)}

Ibn Hazm was born on November 04, 994AD in Cordoba, Spain. His most celebrated work on religions composed is his Kitäb al-Fisal (or: al-fasl) Fil Milal wa Ahwa wa-Nihal which he began to compose most likely somewhere around 1027 and 1030 AD. It comprises of two parts, one about non-Muslim religions, the other about Muslim orders. It additionally contains an uncommon refutation of the Scriptures of 


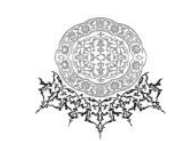

Judaism and Christianity_presumably a second work, embedded later into this book - which might be known as a precursor of modern Bible criticism.

What intrigues us here specifically is the initial segment of the book, since it contains a deliberate portrayal and a nullification of the religions outside Islam which Ibn Hazm knew, treated in a coherent request. In his presentation, Ibn Hazm demonstrates how profoundly he regards reason Other than the peculiarity in which Ibn Hazm goes up against the writings, it is striking to see the entire nonappearance of any recorded treatment in the Kitāb al-Fisal. The creator gives careful consideration to the root and ascent of religious thoughts or to the authentic advancement of the religions he expounds on. He is exceptionally concerned with the doctrinal base and substance of the religions he talks about.

In the wake of having given a graphic rendering of the precepts of a religion, he takes an on a position in his polemical written work and applies a genuinely "cutting edge" scriptural feedback to the sacrosanct writings of that religion, specifically Judaism and Christianity.

He along these lines shows an uncommon basic sense which he joins with an intensive incredulity about all religions outside of Islam. His splendid knowledge, which now and again takes the state of hard logic, is connected to invalidating not just educated missteps and aloofness to truth additionally well-known credulity and superstition, and also false religious powers.

Ibn Hazm had extraordinary impact on later Muslim polemicists against Judaism and Christianity; his contentions, particularly in invalidating the dramatic character what's more, power of the Bible, have been rehashed over and over. He was replied by his contemporary Ibn al-Nagrila (933-1056) who was wazīr (minister) at the time in Granada and much later by Salman Ibn Idris (d. 1310), both having a place with the Jewish people group. Consequently, he gave a devastating answer of Ibn al-Nagrila, which approaches what might be called today anti-Semitic vehemence. ${ }^{4}$

\subsection{Al-Biruni (973 - 1048)}

Al-Biruni born on 4th of September, 973, in a suburb (Birun) of Kath, in the year 1017 al-Biruni was taken as a prisoner to Ghazna in Sijistan. After couple of years the Sultan took al-Biruni with him to India, and left him at some place in northwest India (now Pakistan) for years.

\footnotetext{
${ }^{4}$ Albert Iskandar, “Al-Rāzī," Encyclopedia of the History of Science, Technology, and Medicine in Non-Western Cultures (2nd ed.), Springer (2006): 155-156.
} 


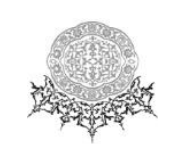

In these years, al-Biruni tried to become more acquainted with the nation where he was living and turned out to be good at it is assumed he did not travel no further than Lahore. It appears that he got impressive guideline from Hindu Pandits and may have adapted some Sanskrit. In these years he wrote his Kitāb Tarikh alHind which was done in the year 1030, shortly before the demise of Sultan Mahmud.

The Kitāb Tarikh al-Hind, which is under consideration here, is a one of a kind endeavor with respect to a Muslim researcher to end up familiar with a totally distinctive culture and perspective on the premise of individual perceptions, questions, and the investigation of Sanskrit writings. Out of the 80 parts of the book, 10 manage religion and theory, 14 with celebrations and folklore, with writing and the investigation of meters in poetry, 14 with geography andcosmography, no less than 31 with chronology and astronomy and 4 with astrology among the Hindus. Part 10, for example, treats the origin of the Hindu "Law" and the Indian "prophets," part 11 , the start of polytheism with a depiction of various statues of divinities; section 63, the Brahmins and their lifestyle; part 64, the rituals and traditions of the lower positions. In the book no less than Sanskrit sources are utilized as a part of expansion to a depiction of various parts of Hindu culture furthermore, a review of religious and philosophical doctrines.

The work remained unknown for quite a while yet, has luckily been found and made open in a content release and an English interpretation of Eduard C. Sachau. What is of interest are al-Biruni's exact examinations concerning Indian culture. $^{5}$ During his likely constrained living arrangement in India, al-Biruni evidently did not enjoy any extraordinary security on Sultan Mahmud's part. His own particular hopelessness, brought on by Mahmud, may have made him thoughtful to Hindus who have gotten a greatly brutal treatment. His association with Hindu researchers did not create problems for him regardless of his goals. Besides, he couldn't go to the genuine focuses of Hindu grant in Benares and Kashmir, al-Biruni must be content with the data given by those individuals whom he could meet and question. ${ }^{6}$ Nevertheless, his own interest and his own particular interest with India, particularly its logic and its inactive monotheism behind a substantial polytheism, empowered him to overcome numerous obstructions and drove him to surprising results.

Al-Biruni's technique is neither sorry nor polemical but instead watching and graphic. He remains at a separation from the material and does not distinguish himself with it. His point is, as he states in the Prologue to his book, to render what

\footnotetext{
${ }^{5}$ Dimitri Gutas, Avicenna and the Aristotelian Tradition, Introduction to Readings: Avicenna's Philosophical Works (Leiden: E.J. Brill, 1988), 242-243.

${ }^{6}$ Ibid., 251-252. 


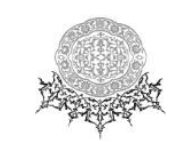

Hindus themselves composed or by and by let him know, with the goal that it is not he himself who depicts regulations, conduct, and Sanskrit renderings but instead those with whom he was in contact. Every part puts forward the issue of the subject treated alongside the Hindus' conventions also, suppositions and al-Biruni's own particular perceptions.

A few of the early parts contain references Muslim studies of other religions to old Greek and Sufi ideas and practices which al-Biruni thinks about to their Indian partners with the reason for clearing up Indian practices and making them more fathomable.

One can see in al-Biruni himself two diverse sets of qualities. From one perspective, he focuses on the predominance of Islam in matters, for example, the equity of all men versus the disparity of the rank framework which he finds indefensible. He underscores the excellencies of the individual law contained in the Shari 'ah contrary to the Hindu law, and the balance of Muslims in examination with the unclean traditions he found among the Hindus. On the other hand, all through his depiction of India al- Biruni altogether deteriorates the Arabs. He attests particularly that the Arabs who decimated the old Iranian culture were no superior to the Zoroastrian Iranians and had traditions which were no superior to the Hindu ones. He more likely than not been glad to be Iranian. Noticeable qualities of al-Biruni are his soul of disclosure, his insightful interest, the reasonable and open path in which he conveys what needs be and his regard for truth. It is this regard for truth which prompts him to unmask conning and cheating, to separate debris from wheat, and persistently to speak to rationale, reason and the laws of nature. In his investigation of Hinduism there are components that have gotten to be major in present-day investigations of religions, particularly in the errand of procuring right data and endeavoring to render the given data more conceivable by method for correlation.

Arthur Jeffery and W. Montgomery Watt broke down al-Biruni's commitment to the investigation of religions as an insightful teach taking religions as subjects of experimental research. ${ }^{7}$

\subsection{Abu Al-Mali}

Little is known about Abu al-Maali's life. His family originated from Balkh and he was a contemporary of Nasir-i-Khusraw (d. somewhere around 1072 and

\footnotetext{
${ }^{7}$ George Saliba, Encyclopadia Britannica, s.v. "al-Biruni," (Chicago: Encyclopedia Britannica, 2006).
} 


\section{상}

1077). Abu al-Maali composed his Kitāb Bayan al-Adyan in the year 1092 in Ghazna amid the rule of Sultan Masud III (1089-1099), additionally called Ala al-Dawla. ${ }^{8}$

The Kitāb Bayan al-Adyan is the most punctual work in Persian about religions and groups. It is little, it has a sudden scholarly style and it does not have an adjusted structure. It was likely composed for pedantic purposes also, implied for non-specialized. The event which gave rise to the composition of the book is not exactly clear; there are just indications as to its root and point. In his presentation the author alludes to a dialog, which probably occurred in a sovereign's court, about different religions and factions and in which the notable Hadith concerning the presence of Islamic factions is alluded to. The creator suggests the way that in this world it is obligatory to comply with the individuals who are in control. He then specifies that preference of his book is that it illuminates the Sunnis of the contentions of their foes and, subsequently, makes their invalidation conceivable. The Sunnis will then observe that they themselves settled on the right decision so that their comprehension and their confidence will increase. The book itself comprises of five parts. The first part treats the possibility of God and the widespread conviction in a Creator who bears diverse names. This part, which peruses like a Muslim religious tract, tosses light in transit in which Abu al-Maali treats his topic and which recognizes him from al-Biruni and al-Shahrastānı̄'s and, to a lesser degree, Ibn Hazm. It closes with the comment that a great many people put stock in a Creator and that they all—each in his own dialect—perceive the god-like novel God under one uncommon name which they call upon in times of hopelessness. "This is the best confirmation of the presence of God," the author finishes up, leaving aside the proofs given in Islamic religious philosophy. ${ }^{9}$

The second section treats those religions which had gone before Islam and which, typically, were in disagreement with each other. The old Arabs head the primary rundown, trailed by the Greek scholars, the Jews, the Christians, the Zoroastrians, the Mazdakites and the Manicheans. The heathens are dealt with in the second place; a critique on the source of excessive admiration goes before dialogs of the Hindus, who are exceptionally applauded for their refinement and knowledge; the Sabians; the Qarmatians and Zindiqs (Manicheans) who deny the presence of a Creator; lastly the Sophists, who put waking on a standard with envisioning.

\footnotetext{
${ }^{8}$ Sharma Arvind, "Studies in “Al-Biruni's India," in Studies in Oriental Religions Vol. 9 (Wiesbaden: Otto Harrassowitz, 1983), vi, 155; S. Pines and T. Gelblum, “Al-Biruni's Arabic Version of Patanjali's Yogasutra," in Bulletin of the School of Oriental and African Studies, Vol. 29 (1966): 302-303.

${ }^{9}$ Alessandro Bausani, “L'India Vista da due Grandi Personalità Musulmane: Babar e Biruni," (India's View from two Great Muslim Figures: Babar and Biruni) in al-Biruni Commemoration Volume, A. H. 362-A. H. 1362 (Calcutta: Iran Society, 1951): 53-76.
} 


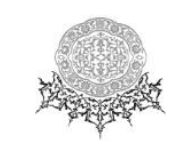

The last three sections progressively treat the Hadith of the Islamic groups, and in addition certain radical mentalities which consider man as God or as prophet. Abu al-Maali utilizes accessible sources, yet uncritically; there are in his book some inaccurate citations from al-Biruni. One ought to accordingly be careful in surveying Abu al-Maali's comments about non-Muslim religions. The best segment of the book is by all accounts that which manages the Shia, specifically the Imamiya or Twelvers. This proposes Abu al-Maali may have been a Twelver Shi $i$ himself for at minimum a piece of his life.

All through the book the impact of Islamic standards and qualities can be felt in the route, for instance, in which non-Islamic religions are characterized. The writer's openness can be found in his status to offer data, without academic demands, about different religions and about Islamic factions to his peers. What is exceptional about the work is that it was written in Persian, as right on time as the end of the eleventh century.

\subsection{Al-Shahrastān̄̄ (1086 -1153)}

Al-Shahrastānī, a native of Shahrastān, a town situated between Naishapūr and Khawarzim, in the Persian province of Khurāsān, was born and lived in a region where many great scholars of the medieval period, both Muslim and non-Muslim, had flourished. Al-Shahrastānī is perhaps best known primarily for his work entitled Mila wa al-Nihal. ${ }^{10}$ This book is regarded by several modem scholars as the first and best in classical Arabic to deal with the science of religion. Thus, Philip K. Hitti, in his History of the Arabs, refers to al-Shahrastānī "the distinguished historian of religion, while Eric J. Sharpe acknowledges that al-Shahrastānī's al-Milal is the first scientific account of the history of religion. ${ }^{11}$ Al-Shahrastānī wrote al-Milal long before the study of the science of religion began to be systematically pursued in Western scholarship. If the book is evaluated within the context of its own time, then it can be regarded as one which gave impetus to a better insight, particularly in methodology; although not in the same sense as in historical modem Western scholarship on religion.

The book al-Milal, however, remained unknown to western scholarship for more than five centuries. It began to become more widely known only after William Cureton's edition of the book. Since then al-Milal has been, for a century, an important source for the study of the history of religions. Students in Europe

${ }^{10}$ Philip K. Hitti, History of the Arabs from Earliest to the Present (London: The Macmillan Press, 1974), 139.

${ }^{11}$ Eric J. Sharpe, Comparative Religion: A History (New York: Charles Scribner's sons, 1975), 11.

JOURNAL OF ISLAMIC THOUGHT AND CIVILIZATION 


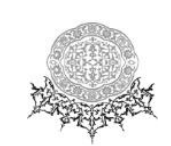

regarded it as an invaluable reference, particularly for the study of the philosophy and religions of the Middle East. ${ }^{12}$

In general, modem scholars in the science of the history of religions tend to consider medieval studies done on the subject of religion to be subjective and full of biased opinions. Contrary to the general views of modem historians of religions, Ahmad Khalifa comes to the conclusion that, through his al-Milal al-Shahrastānī had tried to view the study of religion as essentially a problem of knowledge and its investigation. This is obvious in that al-Shahrastānī makes an effort to provide five introductions in which he explains several important points related to the methodology he uses. The most remarkable contribution of al-Shahrastānī in terms of the methodological aspect Ahmad Khalifah, "Medieval Jewish-Muslim Contribution," is his careful elaboration of the meaning of religion, and his systematic way of classifying the religious data under discussion.

Al-Shahrastānī's had been a charming personality, irreproachable in his lifestyle and blessed with an incredible and exceptionally unique mind. It is realized that he, not at all like a large portion of his partners, had little enthusiasm for juridical inquiries. Then again, he was a gifted author with a clear and discernable style. He is said to have had a hunger for information.

What he writes in his Kitāb al-Milal wa-al-Nihal is generally a presentation of what was known at the time however he does it passionately, without a deliberately conciliatory state of mind. As he himself states, his presentation is without scorn against the one, and without inclination for the other. He utilized existing sources without giving further particular; he picked his materials with care and looked to arrange them properly. He was particularly concerned with portraying principles and frameworks. The book exhibits for all intents and purposes no history, sign of chronicled information or historical points of interest of individuals. The Kitāb al-Milal wal-Nihal comprises of two sections.

The initial segment treats individuals with a religion, that is, those who have gotten a disclosure. They are, for the most part, factions inside Islam and after that those non-Muslims who have scriptures and who are perceived as such by Islam, mostly Jews and Christians. The individuals who have a far-fetched or even misrepresented sacred text like the Zoroastrians and the Manicheans are likewise specified.

The second part treats individuals who have no 'uncovered religion' that is, individuals 'who take after their own slants' (ahl al-ahwa). The first are the Sabians who adore stars and profound creatures; uncommonly, al-Shahrastānī’s incorporates

${ }^{12}$ Alfred Guillaume (ed. and trans.), "Introduction," to The Summa Philosophiae of alShahrastān̄̄'s Kitāb Nihāyat al-Iqdām ilm al-Kalām (Oxford: Oxford University Press, 1934) 


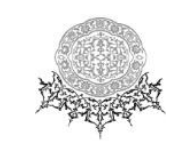

a religious exchange between a Muslim and a Sabian. Second, there are the logicians who constitute all around most of the ahl al-ahwa. Third, there are the polytheists: the pre-Islamic Arabs and also the Hindus (Brahmins, Vaishnavas, and Shaivas), the Buddhists, the star-and icon admirers, and in addition some more logicians.

As already expressed, the book is an arrangement of existing information. There emerges, hence, the issue of al-Shahrastānī's sources, which has been abundantly examined and to which diverse arrangements have been proposed. In any case, the issue has not yet been enough understood, generally on the grounds that specific likely sources do not exist anymore. Inquisitively, al-Biruni was clearly obscure to al-Shahrastānī. Therefore, on first sight the book adds to an interwoven $\theta$ f existing parts composed by others before and after that adjusted off and cleaned into an independent review.

On second sight, notwithstanding, there is a sure framework in it, as was appeared by Bruce B. Lawrence. ${ }^{13}$ By applying certain models in his depictions alShahrastān̄̄'s rehabilitates the Indian religions.

It is a coincident that al-Shahrastān̄̄'s treats Sabianism in the second portion of his book, where the Indian religions are also discussed. For him, it serves as a kind Muslim Studies of other Religions of "model" for a kind of religion that is arranged, so to say, amongst monotheism and polytheism. Sabianism would have been an old religion and there have been assortments of it, similar to the old Sabians themselves, the Greek Sabians, the Indian Sabians, and the later Sabians in Harran. AlShahrastānī's considers the Sabians to have been initially the devotees of the old "prophet" Hermes (Ar. Adhimun), a Hellenistic impactful figure whom Muslims later recognized with the Qur'ānic Idris. The Sabians then deserted Idris' (Adhimun's) prophetic education of the one God. They constituted a specific sort of deviation from genuine monotheism, other than the outstanding deviations held by the Zoroastrians, Jews, and Christians. The Qur'ān specifies without a doubt the Sabians ${ }^{14}$ in a positive sense other than the Christians, the Jews and the Zoroastrians. By exhibiting Indian religion as a type of the pretty much allowable Sabianism, alShahrastānī's tries to "restore" a lot of Hindu thought and religion.

The data which al-Shahrastān̄̄'s gives about the dualists (Zoroastrians and Manicheans) is particularly intriguing. The exuberant civil argument with the Sabians, who are depicted by regulations which used to be credited to them, is additionally fascinating. The author has a decent information of Christian doctrines. He gives a reasonable treatment of Buddhism about which Muslim people group at the time couldn't have known much.

\footnotetext{
${ }^{13}$ Bruce B. Lawrence, "Al- Biruni's Approach to the Comparative Study of Indian Culture," in Biruni Symposium (Calcutta: Iran Society, 1951), 27-47.

${ }^{14}$ Qur'ān, al-Baqara 2:59; al-Maida 05:73; al-Hajj 22:17.
} 


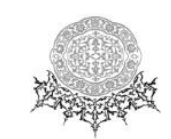

He additionally talks about the presence of "leaves" of disclosure which Ibrahim should have gotten what's more, which would have been the normal base of the religions of the Sabians and Zoroastrians. These takes off were then lost, which thus required the later disclosure. Yet al-Shahrastānī's does not educate much regarding the Jews, and he is fairly concise in his examination of the Isma'ilis in the area on the Islamic groups.

The association of the book satisfies certain stylish and artistic criteria. The author, who composed few other critical religious treatises, was clearly worried to give fundamental data about non-Muslim religions and Muslim factions to his Muslim pursuers. The book has turned into a work of art and is still essential source of data.

\subsection{Analysis}

Where Ibn Hazam stands with the best approaches to refutations famous; al Beiruni treats the religion as a multidimensional phenomenon. He is the least recognized in the mainstream but he is also exceptionally unique and ahead of his own time. Al-Beiruni treats the religion as multidimensional phenomenon along with the least recognized in the main stream but the exceptionally unique and ahead of its own time al Shahrastani, blends the theology and methodological neutralism which are much needed to solve the current debates of insider and outsiders. It reflects the rich traditions of Muslim academia in the field of Religious Studies. As not only Muslim academia stand as the pioneer but at the same time with the diversity of approaches and comprehensive understanding of authors establish himself ahead of its time coping with the field as it is idealistically defined now.

\section{Contemporary Trends of Muslim Scholarship}

If to draw a list of most known and main stream Muslim comparative Religionists from 19th century onwards to contemporary, it will be as below;

\subsection{Rahmatullah Kairanawi (1818 - 1891)}

Rahmatullâh Kairânawî (1818-19) was a Muslim scholar best known for his work Izharul Haqq. The book, Izharul Haqq, reacts to Christian feedback of Islam. It is the primary Muslim book to utilize Western academic works with a specific end goal to find out the mistakes and inconsistencies of the bible. The convention of Trinity is purportedly challenged utilizing scriptural, Christian and different sources. Christine Schirrmacher, a German researcher of Islamic Studies, states in an article on the Pfander-Kairanawi banter about, 'The Demonstration of the Truth' (Izhâr alHaqq) served as a summary of all possible charges against Christianity and was therefore used after al-Kairânawî's death as a sort of encyclopedia since al-Kairânawî 


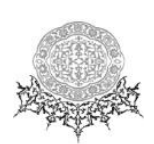

extended the material of former polemicists like 'Ali Tabarî, Ibn Hazm or Ibn Taymiyya to a great extent. ${ }^{15}$

$$
\text { 3.2. Ahmad Deedat (1918 - 2005) }
$$

Ahmad Hossen Deedat (1918-2005) was writer and public speaker of Indian decent. Ahmad Deedat is widely recognized in the field of Comparative Religion in current era based on his public debates on Islam and Christianity. He also wrote booklet on Islam and Christianity but he is mostly recognized because of his public debates famous among them are as below,

1. Debate with John Gilchirst

2. Debate with the Josh McDowell

3. Debates with Anis Shorrosh

4. Debtae with Jimmy Swaggart ${ }^{16}$

$$
\text { 3.3. Ismail Raji al-Faruqi (1921 - 1986) }
$$

Isma'il Raji al-Faruqi (1921-1986) was a palestinian philosopher widely recognized as an authority over comparative Religions. Isma'il have been lecturing the most famous school of Religions, al Azhar, McGill Canada, Temple University to mention the few. He published over 100 articles in various journals and 25 Books. List of his published works include From Here We Start, ${ }^{17}$ Our Beginning in Wisdom, ${ }^{18}$ The Policy of Tomorrow, ${ }^{19}$ Urubah and Religion: An Analysis of the Dominant Ideas of Arabism and of Islam as Its Heights Moment of Consciousness, ${ }^{20}$ Usul al Sahyuniyah fi al Din al Yahudi, ${ }^{21}$ Christian Ethics: A Systematic and Historical Analysis of Its Dominant Ideas, ${ }^{22}$ Islam and the Problem of Israel, ${ }^{23}$

\footnotetext{
${ }^{15}$ Christine Schirrmacher, "The Influence of German Biblical Criticism on Muslim Apologetics in the 19th Century," Contra Mundum, 1997 <https://www.contramundum.org/schirrmacher/rationalism.html>.

${ }^{16}$ Dariusz Dziewanski, "Remembering the life of Sheikh Ahmed Deedat," Al-Jazeera, Accessed August 8, 2015 <http://www1.aljazeera.com/indepth/features/2015/08/remembering-lifesheikh-ahmed-deedat-150803064519593.html.>

${ }^{17}$ Ismail Raji al-Faruqi, From Here we Start, Translation. From the Arabic of K. M. Khalid. (Washington, DC: American Council of Learned Societies, 1953)

${ }^{18}$ Ismail raji al-Faruqi, Our Beginning in Wisdom, tr. from the Arabic of M. al Ghazali. (Washington, DC: American Council of Learned Societies, 1953)

${ }^{19}$ Ismail Raji al-Faruqi, The Policy of Tomorrow, tr. from the Arabic of M. B. Ghali. (Washington, DC: American Council of Learned Societies, 1953)

${ }^{20}$ Ismail Raji al-Faruqi, Urubah and Religion: An Analysis of the Dominant Ideas of Arabism and of Islam as Its Heights Moment of Consciousness, vol. 1 of on Arabism (Amsterdam: Djambatan, 1962)

${ }^{21}$ Ismail Raji al-Faruqi, Usul al Sahyuniyah fi al Din al Yahudi (An Analytical Study of the Growth of Particularism in Hebrew Scripture). [Cairo: Institute of Higher Arabic Studies, 1964)]

${ }^{22}$ Ismail Raji al-Faruqi, Christian Ethics: A Systematic and Historical Analysis of Its Dominant Ideas (Montreal: McGill University Press and Amsterdam: Djambatan, 1968)
} 


\section{닷}

Trialogue of the Abrahamic Faiths, ${ }^{24}$ Islamization of Knowledge, ${ }^{25}$ Tawhid: Its Implications for Thought and Life, ${ }^{26}$ Islam and Other Faiths, ${ }^{27}$ The Cultural Atlas of Islam, ${ }^{28}$ Islam: Religion, Practice, Culture and World Order. ${ }^{29}$ All his posthumous work were updated and edited by Imtiyaz Yusuf.

Most notable being Christian Ethics: A Historical and Systematic Analysis of its dominant ideas. He also established the 'Islamic Studies Group of the American Academy of Religion' and chaired it for ten years. He served as the vice-president of the Inter-Religious Peace Colloquium, The Muslim-Jewish-Christian Conference and as the president of the American Islamic College in Chicago. ${ }^{30}$

\subsection{Zakir Naik (b. 1965)}

Zakir Naik (1965) is an Indian Islamic scholar founder of Comparative Religion Peace TV channel, and also the founder of IRF (Islamic Research Foundation). Mr. Naik Stands as the most famous main stream recognized authority on comparative religions.

Mr. Zakir is best known for his grip over scriptures of other Religions which he use as his best tool in his debates and public lectures. ${ }^{31}$ Naik have said to deliver over 4000 lectures the most famous of his debates are the most famous of his debates are Australia 2004; at university of Melbourne where he mainly argued about women rights in Islam. Gambia 2014; on invitation of president Mr. Naik delivered the Lecture in University of Gambia on Ghambian $20^{\text {th }}$ Revolution anniversary. The Cabinet Ministers of Gambia, religious leaders, students and thousands of people attended his lectures on the subjects including 'Terrorism and Jihad: an Islamic Perspective,' 'Religion in the Right Perspective,' 'Dawah or Destruction?' and 'the Misconceptions about Islam.' Others include the Lectures in wales 2006 and Malysia 2012 and 2016 to mention few. ${ }^{32}$

\footnotetext{
${ }^{23}$ Ismail Raji al-Faruqi, Islam and the Problem of Israel (London: The Islamic Council of Europe, 1980)

${ }^{24}$ Ismail Raji al-Faruqi, Trialogue of the Abrahamic Faiths, ed. (Herndon, 1982)

${ }^{25}$ Ismail Raji al-Faruqi, Islamization of Knowledge. (Herndon, VA: IIIT, 1982)

${ }^{26}$ Ismail Raji al-Faruqi, Tawhid: Its Implications for Thought and Life (Kuala Lumpur: IIIT, 1982)

${ }^{27}$ Ismail Raji al-Faruqi, Islam and Other Faiths (Beltsville, MD: Amana Publications, 1985)

${ }^{28}$ Ismail Raji al-Faruqi, The Cultural Atlas of Islam (New York: Macmillan 1986)

${ }^{29}$ Ismail Raji al-Faruqi, Islam: Religion, Practice, Culture and World Order (London; IIIT,

${ }^{30}$ Muhammad Shafiq, Growth of Islamic Thought in North America: Focus on Isma'il Raji al Faruqi (Amana Publications, 1994)

${ }^{31}$ Dr. ZakirNaik, Islamic Research Foundation. Retrieved 16 April 2011.

${ }^{32}$ Syed Neaz Ahmad, "Justice, Peace and Unity: The Cornerstone of Islam," Saudi Gazette. 31 March 2008. Accessed August 7, 2011.
} 


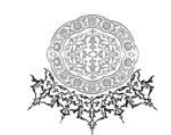

\subsection{Shabir Ally}

Dr. Shabir Ally is a Muslim academic and public speaker in Comparative Religion. Dr. Ally stands the president of the Islamic Information and Dawah Centre International in Toronto, Canada. He is famous for his regular debates with Christian scholars and philosophers. His known Publication includes, Is Jesus God? The Bible Says No, ${ }^{33}$ What God Said About Eating Pork, Science in the Qur'an, 101 Clear Contradictions in the Bible, Yahweh, Jehovah or Allah, 101 Questions to Ask Visiting Jehovah's Witnesses, Reply to Robert Morey's Source of Islam Theories. ${ }^{34}$

\subsection{Yusuf Estes}

Yusuf Estes (1944) is a converted American Preacher who is recognized as a comparative Religionist. Since 1991, Yusuf claims to have been a Muslim Chaplain and to serve the Muslim delegate at United Nation World Peace Conference of Religious Leaders. He has been a keynote Speaker at the various events. ${ }^{35}$

\subsection{Bilal Philips}

Abu Ameenah Bilal Philips, born Dennis Bradley Philips is a Canadian speaker and author famous as per his appearances on Comparative Religion TV Channel "Peace TV." His publication revolving around the field of Comparative Religions are as below, The Purpose of Creation, The True Religion of God, The Fundamentals of Tawheed (Islamic Monotheism), The Evolution of Fiqh (Islamic Law and The Madhhabs), The Clash of Civilizations, True Message of Jesus Christ, 2006; Purpose of Creation, 2002, Polygamy in Islam. ${ }^{36}$

\subsection{Jamal Badawi}

Jamal A. Badawi an Egyptian born Muslim active in many Muslim organizations such as Canadian Council on American-Islamic Relations, the Fiqh Council of North America (FCNA), the Muslim American Society (MAS), and the 'European Council for Fatwa and Research' (ECFR). He is also a member of the Islamic Society of North America (ISNA) and the founder and chairman of the Islamic Information Foundation, a non-profit foundation seeking to promote a better understanding of Islam and Muslims towards non-Muslims. In addition to his participation in lectures, seminars and interfaith dialogues in North America, Badawi

<http://www.webcitation.org/60kgwLkxx?url=http://www.saudigazette.com.sa/index.cfm?method\%3 Dhome.regcon\%26contentID\%3D200803311990\%26archiveissuedate\%3D31/03/2008>

${ }^{33}$ Shabir Ally, Is Jesus God? The Bible Says No (Al-Attique Publications, Canada)

${ }^{34}$ www.shabirally.com; all these publications are published by al-Attique Publications ocated in Canada.

${ }^{35}$ Akbar S. Ahmed, Journey into America: The Challenge of Islam (Brookings Institution Press, 2010), 303; DanialZainalAbidin, Islam the Misunderstood Religion (PTS Millennia, 2007), $180-82$.

\footnotetext{
${ }^{36}$ http://bilalphilips.com; Abu Ameenah BilalPhilips, Hampshire.edu
} 


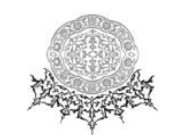

was invited as a guest speaker in various functions throughout the world. In addition to his participation in lectures, seminars and interfaith dialogues in North America, Badawi was invited as a guest speaker in various functions throughout the world. His Publications in the field are: 1,000 Questions on Islam, Gender Equity in Islam (1995); Leadership: An Islamic Perspective (jointly with Beekun Rafiq Issa) 1999, Muhammad in the Bible (Small pamphlet, 1982), Status of Women in Islam (small pamphlet, 1976), Polygamy in Islamic Law, Islam: A Brief Look Small pamphlet. ${ }^{37}$

\subsection{Amir Hussain}

Amir Hussian, the scholar who have the editor of Journal of American Academy of Religion, a flagship journal for the religious studies. His main works which makes him stand in the category of Comparative Religionist are 'World Religions: Western Traditions' and 'World Religions: Eastern Traditions' and the third edition of 'A Concise Introduction to World Religions.' He has written numerous scholarly articles on Islam and Muslims, and is recognized as an authority on Islam in North America. He is a fellow of the Los Angeles Institute for the Humanities. ${ }^{38}$

\section{Decline from Heritage}

Intellectual standards are no doubt to be drawn out of the publications in any field. By just skimming through the list of contemporary publications one can tell how the contemporary Muslim theology is not even in line of its own heritage in the field of Religious studies. Books published are focused on the specifics and the only approach can see is clear refutation. One, off course, cannot deny the utility of such a contemporary work in attracting the masses towards Islam but need of being active and establishing an evolving thought in the field is stands still.

\section{Conclusion}

Brief comparison of the current scholarship in the field of Comparative Religion with those of Muslim heritage reveals the differences of then and now very clearly. As per the heritage Muslims stand as the pioneers of Religious Studies with diversity of approaches and comprehensive understanding of authors which cope with the current modern approaches. But the current works, with few exception proving the rule, demonstrate how the rich heritage have been narrowed down to refutation only. Religious thoughts evolve with the time so one cannot go on refuting them on the basis of same old heritage new researches and analysis are needed to develop better understandings of other Religions in the field with the changing times.

\footnotetext{
${ }^{37}$ William Lane Craig vs. Jamal Badawi," Hot News International. Accessed January 18,
} 2014.

${ }^{38}$ Late Willard G. Oxtoby and Amir Hussain, World Religions: Eastern Traditions (Oxford University Press Canada, 2014)

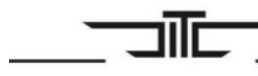

JOURNAL OF ISLAMIC THOUGHT AND CIVILIZATION 


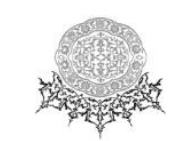

Following the best examples of heritage like those of Al Milal which stands as the best example of Theological based Neutralism Muslim academia may be able to address the biggest debates of insider and out siders as well. Thus it stands the need of hour for Muslim academia to release the importance of its own roots and being connected with them again bring the old fashion back in their work in the field of comparative Religions.

\section{Bibliography}

Ahmed, Akbar S. Journey into America: The Challenge of Islam. Brookings Institution Press, 2010.

Albert, Iskandar. "Al-Rāzī." Encyclopedia of the History of Science, Technology, and Medicine in Non-Western Cultures (2nd ed.). Springer (2006): 155-156.

Christine, Schirrmacher. "The Influence of German Biblical Criticism on Muslim Apologetics in the 19th Century." Contra Mundum, 1997. <https://www.contra-mundum.org/schirrmacher/rationalism.html>.

Dariusz, Dziewanski. "Remembering the life of Sheikh Ahmed Deedat." Aljazeera, $\begin{array}{lll}\text { Accessed August } & \text { 8, }\end{array}$ <http://www1.aljazeera.com/indepth/features/2015/08/remembering-lifesheikh-ahmed-deedat-150803064519593.html>.

Dimitri, Gutas. Avicenna and the Aristotelian Tradition, Introduction to Readings. Avicenna's Philosophical Works. Leiden: E.J. Brill, 1988.

Eric, J. Sharpe. Comparative Religion: A History. New York: Charles Scribner's Sons, 1975.

Guillaume, Alfred. Edited and translated, "Introduction" to The Summa Philosophiae of al-Shahrastānìs Kitāb Nihāyat al-Iqdām ilm-al-Kalām. Oxford: Oxford University Press, 1934.

Hitti, Philip K. History of the Arabs from Earliest to the Present. London: The Macmillan Press, 1974.

Lawrence, Bruce B. “Al- Biruni's Approach to the Comparative Study of Indian Culture." in Biruni Symposium. Calcutta: Iran Society, (1951): 27-47.

Muhammad, Shafiq. Growth of Islamic thought in North America: Focus on Isma'il Raji al Faruqi. Beltsville, MD: Amana Publications, 1994.

Neaz Ahmad, Syed. "Justice, Peace and Unity: The Cornerstone of Islam," Saudi Gazette. 31 March 2008. Accessed August 8, 2011 <http://www.webcitation.org/60kgwLkxx?url=http://www.saudigazette.com. sa/index.cfm?method\%3Dhome.regcon\%26contentID\%3D200803311990\%2 6archiveissuedate\%3D31/03/2008>.

Oxtoby, Willard G. and Amir Hussain. World Religions: Eastern Tradition. Canada: Oxford University Press, 2014. 
Pines S. and T. Gelblum. "Al-Biruni's Arabic Version of Patanjali's Yogasutra." in Bulletin of the School of Oriental and African Studies, 29 (1966)

Russell, McCutcheon. The Insider/Outsider Problem in the Study of Religion. London: Cassell, 1998.

Saliba, George. Encyclopaedia Britannica. s.v. "al-Biruni." Chicago: Encyclopedia Britannica, 2006.

Sharma, Arvind. "Studies in 'Al-Biruni's India." 'Studies in Oriental Religions Vol. 9 Wiesbaden: Otto Harrassowitz, 1983.

William, Thomson. "Islam and the Early Semitic World." The Muslim World 39 (1949): 36-63.

Zainal Abidin, Danial. Islam the Misunderstood Religion. PTS Millennia, 2007. 